\title{
Structure and Composition of Mangrove Associations in Tubli Bay of Bahrain as Affected by Municipal Wastewater Discharge and Anthropogenic Sedimentation
}

\author{
Kholoud Abou Seedo, Mohammad S. Abido, Ahmed Salih, and Asma Abahussain \\ Department of Natural Resources and Environmental Sciences, Arabian Gulf University, Manama, Bahrain \\ Correspondence should be addressed to Mohammad S. Abido; mohammedsaa@agu.edu.bh
}

Received 28 August 2017; Revised 23 November 2017; Accepted 2 December 2017; Published 19 December 2017

Academic Editor: Alexandre Sebbenn

Copyright (C) 2017 Kholoud Abou Seedo et al. This is an open access article distributed under the Creative Commons Attribution License, which permits unrestricted use, distribution, and reproduction in any medium, provided the original work is properly cited.

\begin{abstract}
The effects of municipal wastewater discharge and anthropogenic sedimentation on the structure and composition of gray mangrove (Avicennia marina (Forsk.) Vierh.) communities along Tubli Bay coastlines in Bahrain were investigated. Growth and regeneration of mangrove were measured, and its community was characterized. Sediment profile was analyzed for texture, $\mathrm{pH}$, and salinity. Mangrove area covered by sand depositions was measured using Google Earth Pro. ANOVA and regression tests were employed in the analysis of the data. Results indicated that mangrove overwhelmingly dominated plant community in the study area, which was zoned by a community of other salt-tolerant species. Three main habitats exist in the study area with high similarity in their floristic composition. Species richness and the number of habitats were low due to the aridity and high sediment salinity. The dilution effect of the secondary treated wastewater had a favorable effect on height and diameters of mangrove trees. However, no differences were observed in leaf area index, basal area, and density of mangrove. The long-term accumulation of anthropogenic sedimentation had a detrimental effect on the mangrove community, expressed in swath death of mangrove trees due to root burials and formation of high topography within the community boundaries.
\end{abstract}

\section{Introduction}

Gray mangrove (Avicennia marina (Forsk.) Vierh.) grows naturally in the intertidal zones of the southern coasts of the Arabian Peninsula forming dwarf stands intermingled with salt-tolerant scrub communities [1-3]. Remnant stands of the species are found along the coastlines of Tubli Bay in Bahrain, occupying $6 \%$ of the Bay habitats and $1 \%$ of the total intertidal and shallow water habitat in the country [3]. These stands are fragmented and subject to various forms of anthropogenic pressures, including the discharge of secondary treated wastewater and the sediment effluents of nearby sand washing plants $[4,5]$.

Growth and community development of mangroves vary between regions due to natural, anthropogenic, and historic factors [6-12]. While climatic factors are decisive in controlling the worldwide distribution of mangroves, local site factors, including topography, soil properties, and tide fluctuations, are significant elements affecting variations in structure and composition of mangrove communities [1316]. In dry environments, aridity and high salinity, among other site factors, are the most critical factors that control growth, structure, and composition of mangroves [17, 18]. Studies indicated that gray mangrove survives a broad range of salinity and $\mathrm{pH}$ conditions. However, best growth is reported to be in the range of 5-75\% seawater concentrations [19]. A. marina may reach a height of $1.6 \mathrm{~m}$ and $2.0 \mathrm{~m}$ when grows in pure and mixed stands consecutively in some of the hypersalinity spots along the Red Sea coasts of Egypt [20]. Nevertheless, increasing the salinity of mangrove media is inversely correlated with the plant water relationship, whereas inflow of freshwater modifies salinity gradients, thus yielding a positive effect on growth rates and species diversity of mangrove communities [21-24]. Often, species richness of mangrove communities is linked to the degree of salinity. 


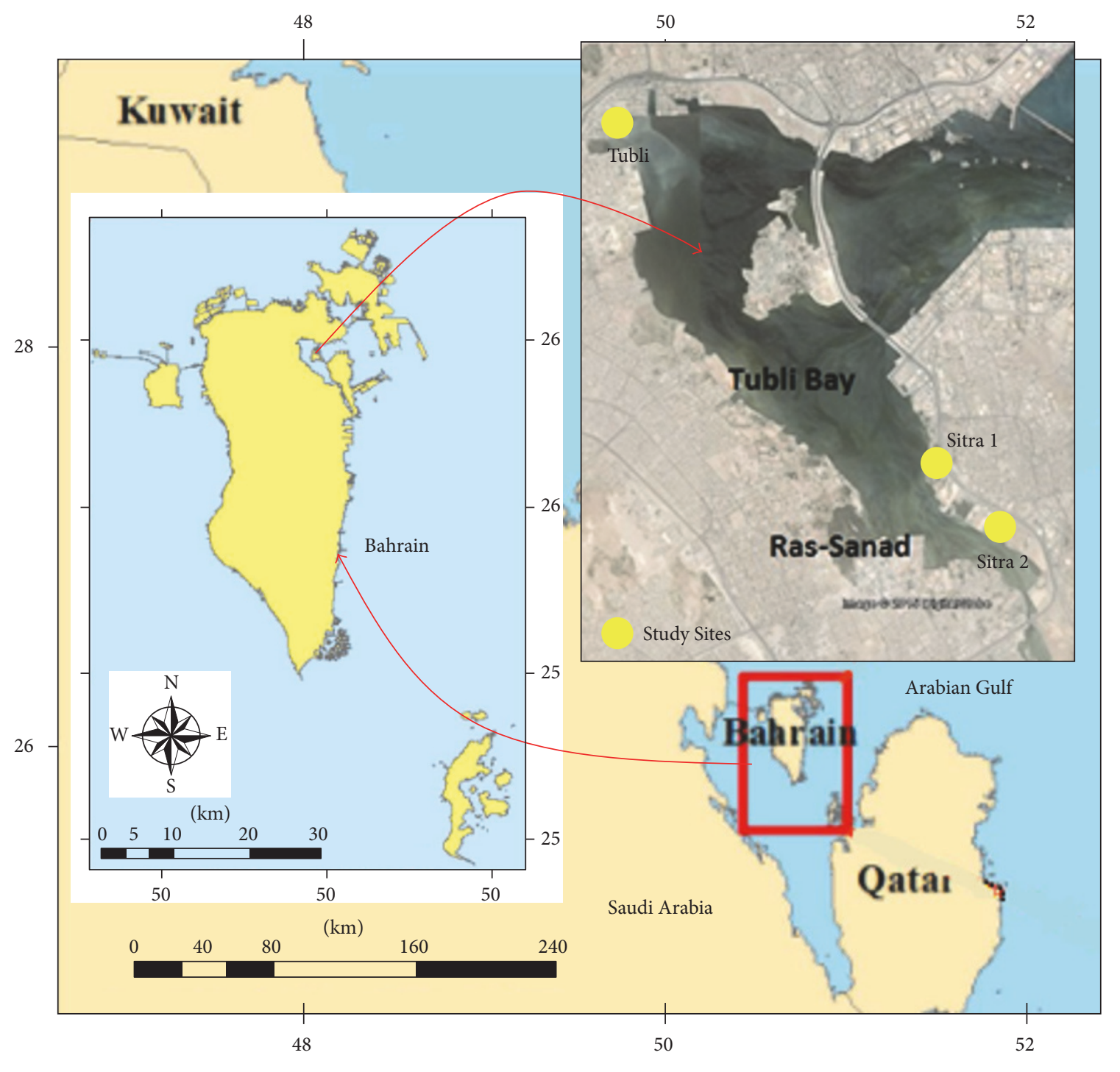

Figure 1: Avicennia marina study sites.

High species richness and diversity were associated with moderate salinity and high moisture content of soil $[7,25]$.

The effect of anthropogenic sedimentation on growth and survival of mangroves is variable and depends on the magnitude, type of sediment, and the degree of species tolerance [22]. Nevertheless, the high rate of sediment accumulation reduces growth, buries the roots, and kills the seedlings [22, 26]. The mechanism of reducing the growth of mangrove and subsequent death of its trees was associated with the smothering effect of sediment on pneumatophores [22]. On the other hand, mangrove architecture and health were related to sediment mud content and deposition patterns of sediment [23].

Characterization of the structure and composition of mangrove communities as affected by modified site conditions is essential for enhancing the conservation effectiveness and implementation of the management plans in light of increasing threats to these forests [27-29]. In the Gulf region, the scientific knowledge on the effect of treated wastewater disposal and sedimentation burials on mangrove is scarce if not lacking. This study aims to investigate the effects of urban wastewater discharge and anthropogenic sedimentation on the structure and composition of mangrove communities along the coastlines of Tubli Bay in Bahrain.

\section{Materials and Methods}

2.1. Study Area. Tubli Bay is an enclosed sea area of $10 \mathrm{Km}^{2}$ in size with an average depth of $2.5 \mathrm{~m}$. It is bounded by urban and agricultural setting as well as causeways which limit water exchange with the open sea. The average salinity of the Bay is $17.5 \mathrm{dsm}^{-1}$ compared to $59.7 \mathrm{dsm}^{-1}$ of the outer sea. Tide occurs twice a day and ranges in heights between 0.20 and $2.62 \mathrm{~m}$. The slope of the intertidal zones of the Bay is $2.2 \%$.

Three mangrove sites were selected along the intertidal zones of Tubli Bay coastlines based on accessibility (Figure 1) [30]. The first site (Tubli) is directly affected by the discharges of approximately $1.2 \mathrm{~m}^{3} \mathrm{Sec}^{-1}$ of secondary treated municipal 


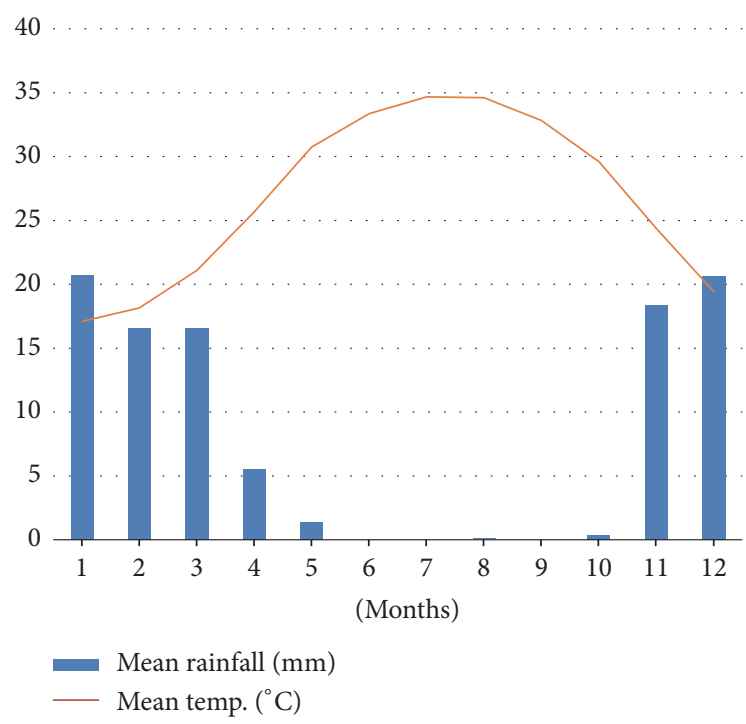

FIGURE 2: Monthly average rainfall $(\mathrm{mm})$ and temperature $\left({ }^{\circ} \mathrm{C}\right)$.

wastewater $[5,6]$. The second site (Sitra-1) had experienced a sedimentation discharge from a nearby sand washing plant for the past 15 years, whereas the third site (Sitra-2) is considered pollution-free [4]. The climate of the study sites is arid, mild in winters, and very hot and humid in summers. Rainfall is scanty and sporadic averaging $80 \mathrm{mmy}^{-1}$. The yearly average temperature is $26.8^{\circ} \mathrm{C}$ and the annual evaporation rate reaches $2000 \mathrm{~mm} \mathrm{y}^{-1}$ (Figure 2) [31].

\subsection{Methods}

2.2.1. Vegetation Analysis. Three replicated plots of $10 \mathrm{~m} \times$ $10 \mathrm{~m}$ were established randomly in the seaward landward direction at each study site. Within these plots, heights and diameters of trees ( $30 \mathrm{~cm}$ above ground level) were measured with a graduated wooden staff and diameter tape accordingly $[32,33]$. Heights and diameters of pneumatophores as well as seedling heights were measured in a $1 \times 1 \mathrm{~m}$ subplots located in the middle of each larger plot. Leaf area index (LAI) was estimated in each plot using CI-110 Plant Canopy Imager. Species cover was measured using a 60-meter long transects stretched along the middle of each larger plot with a sea to landward direction; subsequently, species coverage, density, frequency, and importance value index (IVI) were computed for each plot $[32,33]$. Species similarity and diversity were calculated using Sorensen-Dice coefficient [34] and Simpson's index [35], respectively. Life forms and habitats of encountered species were categorized according to $[36,37]$, respectively. Identification of associated species was based on [38].

2.2.2. Media Analysis. A sediment core $(10 \mathrm{~cm} \times 2 \mathrm{~cm})$ was taken from the center of each plot in the three sites at three depths $(0-5,5-15$, and $15-30 \mathrm{~cm})$. After processing the samples, soil texture by depth was determined using a soil texture triangle calculator [39]. Sediment electrical conductivity (EC) and $\mathrm{pH}$ were measured according to [40].
For each plot in the three sites, water samples were taken, 30-60 minutes of low tide time. A subsample, $50 \mathrm{ml}$ of seawater sample, was used to measure EC and $\mathrm{pH}$ using conductivity and $\mathrm{pH}$ meters, respectively.

2.2.3. Statistical Analysis. Measured parameters were analyzed at $p \leq 0.05$ using ANOVA and regression analysis employing the JMP11 statistical software [41]. Accumulative sediment spread effects were measured as a percentage of mangrove area covered by sand washing plant depositions using Google Earth Pro and ground truthing. Fieldwork was conducted at times of low tide during the period of September 2014 to June 2015.

\section{Results and Discussion}

3.1. Community Structure. The results of the study revealed that the heights of mangroves in the study sites ranged between 1 and $5.5 \mathrm{~m}$ with an average of $2.7 \mathrm{~m}$. Trees were mainly of multiple trunks, ranging from 2 to 5 stems per plant. Diameters of trees ranged in size from 2.2 to $12.5 \mathrm{~cm}$ with a mean of $5.3 \mathrm{~cm}$. Mean density and basal area of mangrove trees were 4576.8 tree ha ${ }^{-1}$ and $11.4 \mathrm{~m}^{2} \mathrm{ha}^{-1}$, respectively. The heights and diameters of trees in Tubli site were $3.25 \mathrm{~m}$ and $5.82 \mathrm{~cm}$, respectively. Tree heights were significantly higher $(p \leq 0.05)$ in the Tubli stand as compared to Sitra (2) but not Sitra (1) (Table 1). Moreover, no significant differences in the height of trees were observed between the Sitra (1) and Sitra (2) stands. High growth parameters could be attributed to the dilution effect of discharged wastewater where measured EC of seawater at Tubli site was $13.2 \pm 2$ compared to 18.8 $\pm 2 \mathrm{dS} \mathrm{m}^{-1}$ and $17.1 \pm 2 \mathrm{dS} \mathrm{m}^{-1}$ in Sitra-1 and Sitra- 2 sites, respectively. However, the insignificance in the height of trees between Tubli site and Sitra (1) could be related to the larger density of trees in the second site, though not significant per se between the two sites. Also, tree diameters were significantly higher $(p \leq 0.05)$ in the Tubli stand as compared to the Sitra (1) and Sitra (2) stands with no observed significant differences between diameters of trees in the last two sites. On the other hand, no differences in density, basal area, and LAI were observed between the three sites (see Table 1).

In the meantime, the sediment salinity level of soil profiles varied among the sites and ranged from a low value of $10.3 \mathrm{dS} \mathrm{m}^{-1}$ in Tubli to $23.2 \mathrm{dS} \mathrm{m}^{-1}$ in Sitra-2. The average salinity levels were $13.72 \mathrm{dS} \mathrm{m}^{-1}, 19.57 \mathrm{dS} \mathrm{m}^{-1}$, and $22.27 \mathrm{dS} \mathrm{m}^{-1}$ in Tubli, Sitra-1, and Sitra-2, respectively. In this context, it was reported that wastewater discharge had a positive effect on seedlings of mangroves through enhancement of growth and reducing the salt-induced damage to the physiological processes of plants [42].

Physiognomically, the lower heights and small diameters of Tubli Bay mangroves reflect low structural stand development according to [43]. The shrubby form of mangrove in this part of the world could be attributed to the aridity of the environment in the first place and secondly to the high salinity in the study area [44-46]. The effect of salinity on mangrove is a controversial issue due to variations in site 


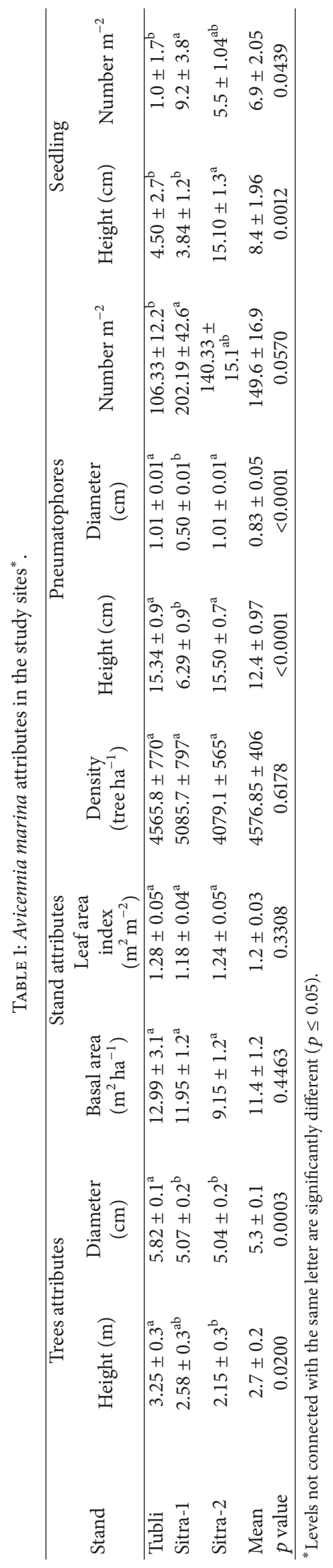


TABLE 2: Correlation coefficient $(r)$ between growth and soil variables at $p<0.05$.

\begin{tabular}{lccr}
\hline Growth variables & Soil variables & Cor. coefficient $(r)$ & Prob. \\
\hline Tree height $(\mathrm{m})$ & EC & -0.90 & 0.284 \\
Trunk diameter $(\mathrm{cm})$ & EC & -1.00 & 0.052 \\
Tree height $(\mathrm{m})$ & $\mathrm{pH}$ & 0.95 & 0.198 \\
Trunk diameter $(\mathrm{cm})$ & $\mathrm{pH}$ & 0.78 & 0.430 \\
Tree height $(\mathrm{m})$ & Sand & -0.59 & 0.602 \\
Trunk diameter $(\mathrm{cm})$ & Sand & -0.84 & 0.370 \\
Tree height $(\mathrm{m})$ & Silt & 0.90 & 0.290 \\
Trunk diameter $(\mathrm{cm})$ & Silt & 1.00 & 0.060 \\
Tree height $(\mathrm{m})$ & Clay & -0.12 & 0.925 \\
Trunk diameter $(\mathrm{cm})$ & Clay & 0.24 & 0.843 \\
\hline
\end{tabular}

TABLE 3: Sediment properties of Avicennia marina stand in the study sites.

\begin{tabular}{|c|c|c|c|c|c|c|c|}
\hline \multirow{3}{*}{ Site } & \multirow{3}{*}{ Depth $(\mathrm{cm})$} & \multicolumn{6}{|c|}{ Soil properties } \\
\hline & & \multicolumn{3}{|c|}{ Texture (\%) } & \multirow{2}{*}{$\begin{array}{l}\text { Soil texture } \\
\text { Sandy loam }\end{array}$} & \multirow{2}{*}{ Salinity $\left(\mathrm{dS} \mathrm{m}^{-1}\right)$} & \multirow{2}{*}{$\mathrm{pH}$} \\
\hline & & Clay & Silt & Sand & & & \\
\hline \multirow{3}{*}{ Tubli } & $0-5$ & $17.99^{\mathrm{bcd}}$ & $19.99^{\mathrm{cd}}$ & $62.02^{\mathrm{ab}}$ & Sandy loam & $16.2^{\mathrm{bc}}$ & $8.02^{\mathrm{a}}$ \\
\hline & $5-15$ & $12.00^{\mathrm{d}}$ & $9.32^{\mathrm{d}}$ & $78.68^{\mathrm{a}}$ & Sandy loam & $14.7^{\mathrm{cd}}$ & $8.04^{\mathrm{a}}$ \\
\hline & $15-30$ & $19.99^{\mathrm{bc}}$ & $10.00^{\mathrm{d}}$ & $70.02^{\mathrm{a}}$ & Loam & $10.3^{\mathrm{d}}$ & $8.00^{\mathrm{ab}}$ \\
\hline \multirow{3}{*}{ Sitra-1 } & $0-5$ & $18.66^{\mathrm{bcd}}$ & $38.65^{\mathrm{a}}$ & $42.68^{\mathrm{cd}}$ & Loam & $20.9^{\mathrm{ab}}$ & $7.93^{\mathrm{abc}}$ \\
\hline & $5-15$ & $23.32^{\mathrm{abc}}$ & $43.30^{\mathrm{a}}$ & $33.37^{\mathrm{cd}}$ & Clay loam & $18.0^{\mathrm{abc}}$ & $7.83^{\mathrm{bcd}}$ \\
\hline & $15-30$ & $29.32^{\mathrm{a}}$ & $43.31^{\mathrm{a}}$ & $27.36^{\mathrm{d}}$ & Sandy clay Loam & $19.8^{\mathrm{abc}}$ & $8.02^{\mathrm{a}}$ \\
\hline \multirow{3}{*}{ Sitra-2 } & $0-5$ & $23.30^{\mathrm{abc}}$ & $26.63^{\mathrm{bc}}$ & $50.07^{\mathrm{bc}}$ & Loam & $18.2^{\mathrm{abc}}$ & $7.71^{d}$ \\
\hline & $5-15$ & $24.62^{\mathrm{ab}}$ & $35.92^{\mathrm{ab}}$ & $39.46^{\mathrm{cd}}$ & Sandy loam & $23.2^{\mathrm{a}}$ & $7.71^{\mathrm{d}}$ \\
\hline & $15-30$ & $15.96^{\mathrm{cd}}$ & $19.95^{\mathrm{cd}}$ & $64.09^{\mathrm{ab}}$ & Sandy loam & $16.4^{\mathrm{bc}}$ & $7.78^{\mathrm{cd}}$ \\
\hline
\end{tabular}

Levels not connected with the same letter are significantly different $(p \leq 0.05)$.

salinities. Salinity was reported as a necessity for the better growth of mangrove [47] while other scholars considered mangrove insensitive to wide ranges of salinity fluctuations $[10,48,49]$. In our study, negative correlation existed between tree heights and EC (-0.9) and between trunk diameters and EC (-1.0), although not significant, probably due to a small sample size. Likewise, positive correlation (0.9) existed between the heights of trees and silt content of the soil profile. Also, the correlation coefficient was not significant between diameters of trees and the silt content of the soil profile (Table 2).

The canopy of trees was relatively open as LAI ranged between 0.58 and 2.4 averaging $1.23 \pm 0.03$, which is within the range values reported by [50] for the species. Pneumatophores mean height $(12.4 \pm 1 \mathrm{~cm})$ and density $\left(149.6 \pm 16.9 \mathrm{~m}^{-2}\right)$ were significantly different between sites. Lowest number of pneumatophores was observed at Tubli site (106.33), which could be attributed to the effect of sewage discharge as indicated by [51]. The least heights of pneumatophores $(6.29 \mathrm{~cm})$ and their maximum number (202) per square meter in the Sitra-1 site could be attributed to sediment deposition where nearly $80 \%$ of pneumatophores heights were buried in a $30 \mathrm{~cm}$ white-layer depth of silt. Differences in pneumatophores density were ascribed to the microtopographic features [52] and the anaerobic circumstance of sites caused by mud content as well as waterlogging
[53]. The silt percentage of the soil profile in the Sitra-1 site ranged from 38.65 at $0-5 \mathrm{~cm}$ depth to 43.31 at $15-30 \mathrm{~cm}$, averaging $41.75 \%$, which is considerably higher than the silt particle percentages in comparable depths of the other two sites due to the siltation from the nearby sand washing plant (Table 3). Average portions of silt particles in soil profile were $27.5 \%$ and $13.10 \%$ in Sitra- 2 and Tubli site, respectively.

Finally, the number of seedlings among sites varied from one seedling per square meter in Tubli site to more than nine seedlings in Sitra-1. The presence of microtopography created by the siltation process in Sitra-1 site compared to the other two sites may facilitate seedlings establishments and regeneration of trees [54-56]. The number of seedlings in the Sitra-1 site was significantly higher than those of the other two sites. In the meantime, the height of seedlings $(3.84 \mathrm{~cm})$ in Sitra-1 was the least compared to $4.5 \mathrm{~cm}$ and $15.1 \mathrm{~cm}$ in Tubli and Sitra-2 sites consecutively due to sediment deposition. Statistically, the height of seedlings in Sitra-2 differed significantly than those of Tubli and Sitra-1.

3.2. Community Composition. In Tubli site, the relative cover of mangrove averaged $41.4 \%$ compared to $52.1 \%$ and $54.7 \%$ in Sitra- 1 and Sitra- 2 consecutively. Relative density was $98.5 \%$ and $93.6 \%$ in Tubli and Sitra-1, respectively, compared to $100 \%$ in Sitra-2. Relative frequency was $75 \%$ in the site of 


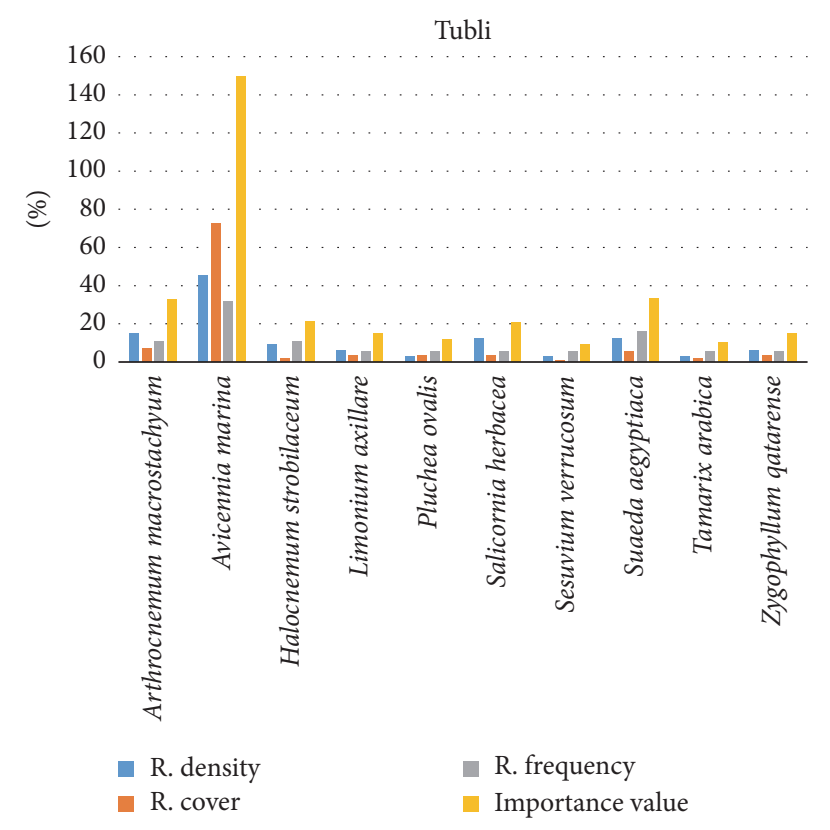

FIGURE 3: Relative density, cover, frequency, and importance values for Tubli site mangrove stand.

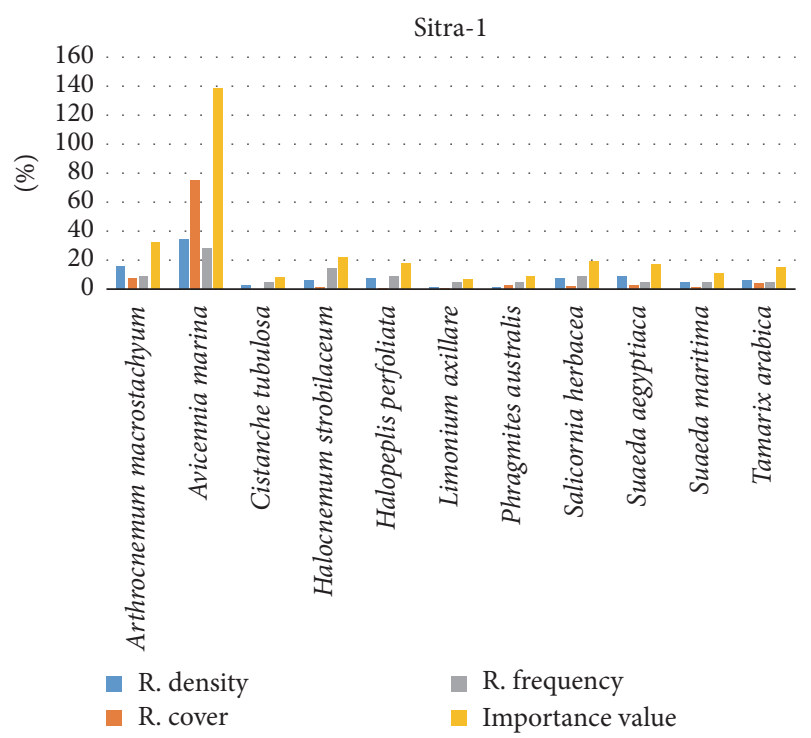

FIGURE 4: Relative density, cover, frequency, and importance values for Sitra-1 mangrove stand.

Tubli, while it registered $92.4 \%$ and $91.7 \%$ in Sitra-1 and Sitra2. High relative density figures reveal the purity of mangrove stands in all study sites. IVI for mangrove were relatively similar in the three sites ranging between 138.7 and 155.7 reflecting a clear dominance of the existing plant communities. In the meantime, IVI for the other associated species were of low values reaching, for instance, a maximum of 33 for Arthrocnemum macrostachyum in both Tubli and Sitra (1) sites to 39 in Sitra (2) (Figures 3-5). On the other hand,

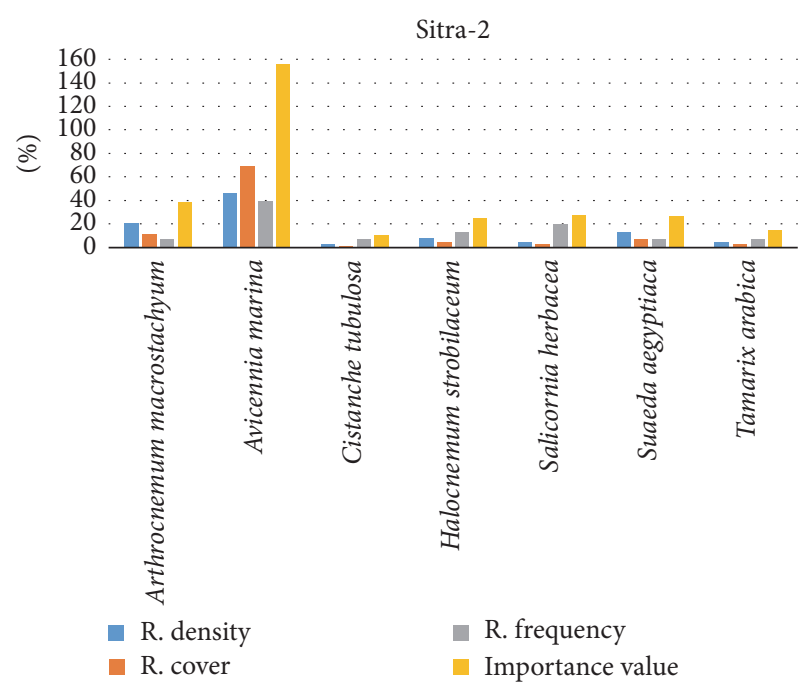

FIGURE 5: Relative density, cover, frequency, and importance values for Sitra-2 mangrove stand.

infrequent tide flushing and hypersalinity formed mangrovesalt marsh ecotones where salt-tolerant species like Halocnemum strobilaceum, Suaeda aegyptiaca, Suaeda maritima, Halopeplis perfoliata, Arthrocnemum macrostachyum, and Salicornia herbacea (Table 4) were zoned beyond the dense mangrove areas. The inadequate flushing and the hypersalinity conditions were highlighted by [17] as the two decisive factors affecting mangrove growth and distribution, which is the case in this region.

Three main habitats were identified in the study sites. These habitats were mangrove submerged roots (MSR), lower salt marshes (LSM), and the upper salt marshes (USM). Chamaephytes constitute more than $50 \%$ of life forms in the study sites. Species similarity between Tubli and Sitra-1 was $67 \%$, compared to $71 \%$ between Tubli and Sitra-2 and $78 \%$ between Sitra-1 and Sitra-2 consecutively. Simpson diversity index of species was $0.72,0.82$, and 0.72 for Tubli, Sitra-1, and Sitra-2 sites sequentially.

3.3. Siltation Effects. Sediment texture in the study sites was sandy loam in Tubli site, loam to clay loam in Sitra-1, and sandy clay loam/loam to sandy loam in Sitra-2 (see Table 3). Sand dominated sediment profile in Tubli site is due to reclamation activities, while in Sitra-2 the sediment profile was more balanced as no human intervention was observed on the site. On the other hand, silt dominated the main component of the soil profile in Sitra-1 plots (39-43\%) due to prolonged siltation effects of nearby sand washing plants. Significant differences existed in soil texture between the three sites and between depths of each site.

The effect of siltation on the structure and composition of mangroves was evident in elevating site topography which prevented frequent tide inundation of these areas. The occasional flooding permitted Halopeplis perfoliata, an annual halophyte species, to proliferate in these spots. Further, in May of 2015, sudden mangrove mortality was observed at the site along the path of sediment release as a swath measuring 
TABLE 4: List of mangrove associated species, families, life forms, and habitats in the study sites.

\begin{tabular}{|c|c|c|c|c|c|c|c|}
\hline \multirow{2}{*}{ Number } & \multirow{2}{*}{ Plant species } & \multirow{2}{*}{ Family } & \multirow{2}{*}{ Life form } & \multirow{2}{*}{ Habitat } & \multicolumn{3}{|c|}{ Sites } \\
\hline & & & & & Tubli & Sitra-1 & Sitra-2 \\
\hline (1) & Arthrocnemum macrostachyum & Chenopodiaceae & $\mathrm{Ch}$ & LSM & - & $\sqrt{ }$ & $\sqrt{ }$ \\
\hline (2) & Avicennia marina & Avicenniaceae & $\mathrm{Ph}$ & MSR & $\sqrt{ }$ & $\sqrt{ }$ & $\sqrt{ }$ \\
\hline (3) & Cistanche tubulosa & Orobanchaceae & $\mathrm{Cr} / \mathrm{P}$ & USM & - & $\sqrt{ }$ & $\sqrt{ }$ \\
\hline (4) & Citrullus colocynthis & Cucurbitaceae & $\mathrm{He}$ & USM & - & $\sqrt{ }$ & - \\
\hline (5) & Halocnemum strobilaceum & Amaranthaceae & $\mathrm{Ch}$ & LSM & $\sqrt{ }$ & $\sqrt{ }$ & $\sqrt{ }$ \\
\hline (6) & Halopeplis perfoliata & Chenopodiaceae & $\mathrm{Ch}$ & LSM & - & $\sqrt{ }$ & - \\
\hline (7) & Limonium axillare & Plumbaginaceae & $\mathrm{Ch}$ & USM & $\sqrt{ }$ & - & - \\
\hline (8) & Phragmites australis & Poaceae & $\mathrm{Cr}$ & USM & - & $\sqrt{ }$ & - \\
\hline (9) & Pluchea ovalis & Asteraceae & $\mathrm{Ph}$ & USM & $\sqrt{ }$ & - & - \\
\hline (10) & Salicornia herbacea & Chenopodiaceae & Th & LSM & $\sqrt{ }$ & $\sqrt{ }$ & $\sqrt{ }$ \\
\hline (11) & Sesuvium verrucosum & Aizoaceae & $\mathrm{Ch}$ & USM & $\sqrt{ }$ & - & - \\
\hline (12) & Suaeda aegyptiaca & Chenopodiaceae & $\mathrm{Ch}$ & LSM & $\sqrt{ }$ & $\sqrt{ }$ & $\sqrt{ }$ \\
\hline (13) & Suaeda maritima & Chenopodiaceae & $\mathrm{Ch}$ & LSM & - & $\sqrt{ }$ & - \\
\hline (14) & Tamarix arabica & Tamaricaceae & $\mathrm{Ph}$ & USM & $\sqrt{ }$ & $\sqrt{ }$ & $\sqrt{ }$ \\
\hline (15) & Zygophyllum qatarense & Zygophyllaceae & $\mathrm{Ch}$ & USM & $\sqrt{ }$ & - & - \\
\hline
\end{tabular}

Ch: Chamaephytes, Cr: Cryptophytes, He: Hemicryptophytes, P: parasite, Ph: Phanerophyte, Th: Therophytes, LSM: lower salt marsh, MSR: mangrove submerged root, and USM: upper salt marsh.

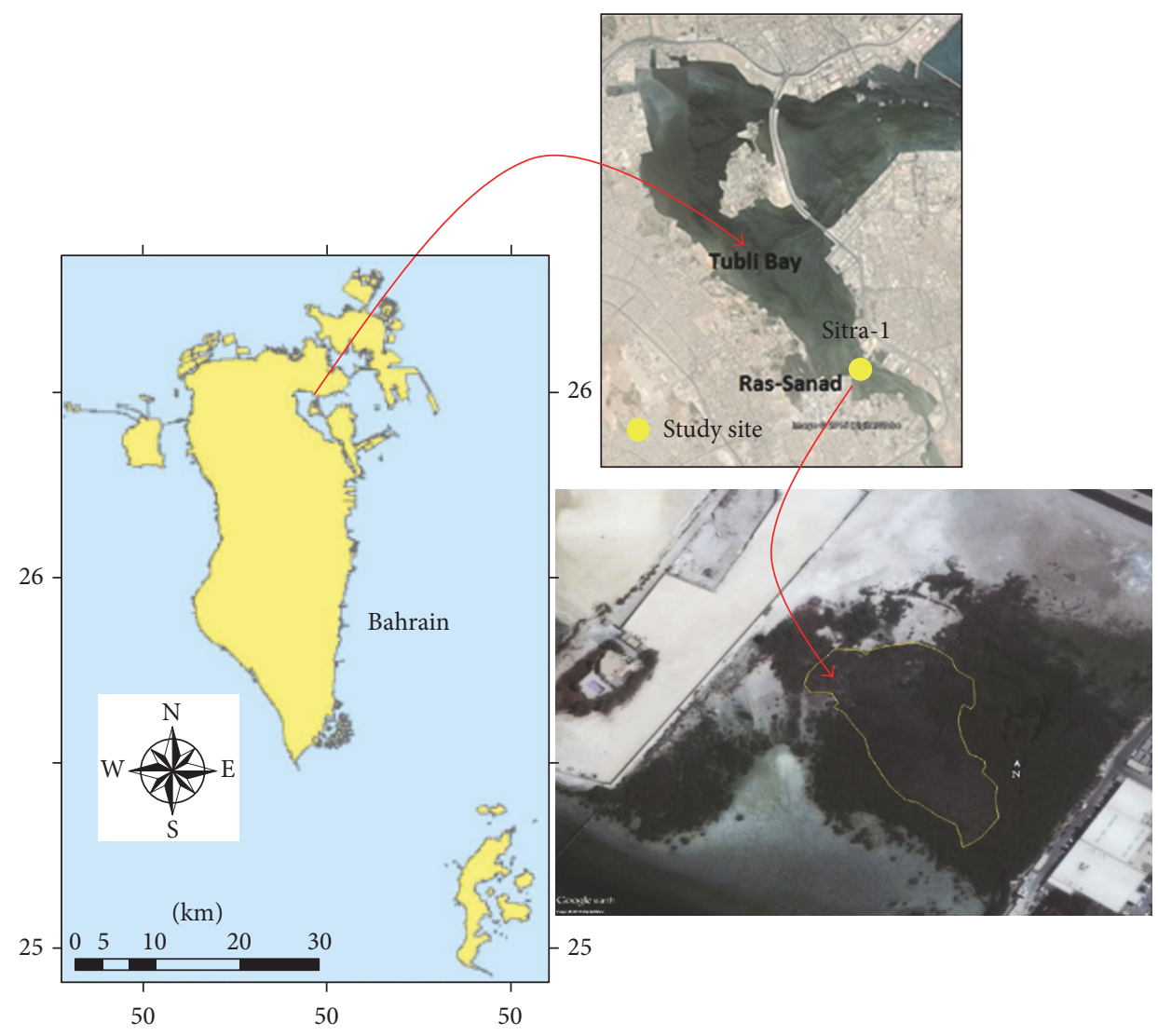

FIGURE 6: Mangrove death due to silt accumulation in Sitra-1 site.

$40 \mathrm{~m}$ in width and $160 \mathrm{~m}$ in length which are equivalent to $22 \%$ of the stand area, possibly due to the effect of long-term silt accumulation (Figure 6). Various authors reported the detrimental effects of siltation on root aeration of mangroves, which eventually leads to the death of mangroves [22, 24, 57].

\section{Conclusions}

Mangrove formed pure plant communities along the coastlines of Tubli Bay, intermingled in some cases with other salt-tolerant species. The aridity of the environment, salinity, 
and the extent of the tide flooded area contributed to the formation of a few species salt-tolerant plant community in the study sites. The structure and composition of mangrove communities were similar in all of the study sites. Nevertheless, wastewater discharge had a positive effect on heights and diameters of mangrove trees in Tubli site due to the dilution effect of secondary treated wastewater. In the meantime, anthropogenic siltation had a detrimental impact on mangroves on the exposed site (Sitra-1) by excluding mangroves from some spots and burying roots of the species which led eventually to swath death in the stand. Further investigation is needed to reveal the exact cause and mechanism of positive mangrove response to wastewater discharge and the death mechanism caused by sedimentation in mangroves of Tubli Bay.

\section{Conflicts of Interest}

The authors of this paper declare that there are no conflicts of interest regarding the publication of this work.

\section{Acknowledgments}

This study was conducted within the framework of the research plan of the Department of Natural Resources and Environment, Arabian Gulf University.

\section{References}

[1] M. Spalding, M. Kainuma, and L. Collins, World Atlas of Mangroves, A collaborative project of ITTO, ISME, FAO, UNEPWCMC, UNESCO-MAB, UNU-INWEH and NC, 319, EarthScan, London, UK, 2010.

[2] A. M. Al-Ali, A. G. Del Campo, and C. Rocha, "Environmental assessment of mangrove communities in Tarut bay, eastern Arabian peninsula, based on multidisciplinary approach," in Proceedings of the 2015 36th International Symposium on Remote Sensing of Environment, pp. 269-276, Germany, May 2015.

[3] D. H. Vousden, Bahrain Marine Habitats and some Environmental Effects on Seagrass Beds, A Ph.D. Thesis submitted to the University of Wales [Ph.D. thesis], 1995, http://e.bangor.ac.uk/4257/ 1/DX202943.pdf.

[4] H. A. Naser, "The role of environmental impact assessment in protecting coastal and marine environments in rapidly developing islands: The case of Bahrain, Arabian Gulf," Ocean \& Coastal Management, vol. 104, pp. 159-169, 2015.

[5] HYBACS, Municipal Sewage: Tubli, Bahrain, 2013, http:// www.bluewaterbio.com/wp-content/uploads/2015/10/Tubli Municipal-Sewage_Rev8.pdf.

[6] K. A. R. S. Perera, M. D. Amarasinghe, and S. Somaratna, "Vegetation structure and species distribution of mangroves along a soil salinity gradient in a micro tidal estuary on the northwestern coast of Sri Lanka," American Journal of Marine Science, vol. 1, no. 1, p. 15, 2013.

[7] N. C. Duke, M. C. Ball, and J. C. Ellison, "Factors influencing biodiversity and distributional gradients in mangroves," Global Ecology and Biogeography Letters, vol. 7, no. 1, pp. 27-47, 1998.

[8] S. C. L. Hoppe-Speer, J. B. Adams, A. Rajkaran, and D. Bailey, "The response of the red mangrove Rhizophora mucronata Lam. to salinity and inundation in South Africa," Aquatic Botany, vol. 95, no. 2, pp. 71-76, 2011.

[9] H. Joshi and M. Ghose, "Forest structure and species distribution along soil salinity and $\mathrm{pH}$ gradient in mangrove swamps of the Sundarbans," Tropical Ecology, vol. 44, no. 2, pp. 197-206, 2003.

[10] E. D. Hastuti, S. Anggoro, and R. Pribadi, "The effects of environmental factors on the dynamic growth pattern of mangrove Avicennia marina," Journal of Coastal Development, vol. 16, no. 1, pp. 57-61, 2012.

[11] C. Giri, E. Ochieng, L. L. Tieszen et al., "Status and distribution of mangrove forests of the world using earth observation satellite data," Global Ecology and Biogeography, vol. 20, no. 1, pp. 154-159, 2011.

[12] J. A. Allen, K. W. Krauss, and R. D. Hauff, "Factors limiting the intertidal distribution of the mangrove species Xylocarpus granatum," Oecologia, vol. 135, no. 1, pp. 110-121, 2003.

[13] L. E. Urrego, E. C. Molina, and J. A. Suárez, "Environmental and anthropogenic influences on the distribution, structure, and floristic composition of mangrove forests of the Gulf of Urabá (Colombian Caribbean)," Aquatic Botany, vol. 114, pp. 42-49, 2014.

[14] M. D. Hossain and A. A. Nuruddin, "Soil and mangrove: A review," Journal of Environmental Science and Technology, vol. 9, no. 2, pp. 198-207, 2016.

[15] K. L. McKee and P. L. Faulkner, "Restoration of biogeochemical function in mangrove forests," Restoration Ecology, vol. 8, no. 3, pp. 247-259, 2000.

[16] K. Kathiresan and B. L. Bingham, "Biology of mangroves and mangrove ecosystems," Advances in Marine Biology, vol. 40, pp. 81-251, 2001.

[17] K. Quisthoudt, N. Schmitz, C. F. Randin, F. Dahdouh-Guebas, E. M. R. Robert, and N. Koedam, "Temperature variation among mangrove latitudinal range limits worldwide," Trees Structure and Function, vol. 26, no. 6, pp. 1919-1931, 2012.

[18] A. K. Sawale and G. A. Thivakaran, "Structural Characteristics of Mangrove Forest of Kachchh, Gujarat," Journal of the Marine Biological Association of India, vol. 55, no. 1, pp. 5-11, 2013.

[19] K. W. Krauss, C. E. Lovelock, K. L. McKee, L. López-Hoffman, S. M. L. Ewe, and W. P. Sousa, "Environmental drivers in mangrove establishment and early development: A review," Aquatic Botany, vol. 89, no. 2, pp. 105-127, 2008.

[20] A. El-Khouly and K. A. Abdel-Hamid, "Zonation pattern of Avicennia marina and Rhizophora mucronata along the Red Sea coast, Egypt," World Applied Sciences Journal, vol. 2, no. 4, pp. 283-288, 2007, https://idosi.org/wasj/wasj2(4)/4.pdf.

[21] J. C. Ellison, "Impacts of sediment burial on mangroves," Marine Pollution Bulletin, vol. 37, no. 8-12, pp. 420-426, 1999.

[22] J. Ellis, P. Nicholls, R. Craggs, D. Hofstra, and J. Hewitt, "Effects of terrigenous sedimentation on mangrove physiology and associated macrobenthic communities," Marine Ecology Progress Series, vol. 270, pp. 71-82, 2004.

[23] U. Thampanya, J. E. Vermaat, and J. Terrados, "The effect of increasing sediment accretion on the seedlings of three common Thai mangrove species," Aquatic Botany, vol. 74, no. 4, pp. 315-325, 2002.

[24] M. C. Ball, "Mangrove species richness in relation to salinity and waterlogging: a case study along the Adelaide River floodplain, northern Australia," Global Ecology and Biogeography Letters, vol. 7, no. 1, pp. 73-82, 1998. 
[25] F. Sidik, D. Neil, and C. E. Lovelock, "Effect of high sedimentation rates on surface sediment dynamics and mangrove growth in the Porong River, Indonesia," Marine Pollution Bulletin, vol. 107, no. 1, pp. 355-363, 2016.

[26] H. M. Guzman, P. A. G. Barnes, C. E. Lovelock, and I. C. Feller, "A site description of the CARICOMP mangrove, seagrass and coral reef sites in Bocas del Toro, Panama," Caribbean Journal of Science, vol. 41, no. 3, pp. 430-440, 2005.

[27] L. Townsend, "Ecological site descriptions: Developmental considerations for woodlands and forests," Rangelands, vol. 32, no. 6, pp. 37-42, 2010.

[28] C. Sheppard, M. Al-Husiani, F. Al-Jamali et al., "The Gulf: A young sea in decline," Marine Pollution Bulletin, vol. 60, no. 1, pp. 13-38, 2010.

[29] CARICOMP, CARICOMP methods manual, levels 1 and 2: manual of methods for mapping and monitoring of physical and biological parameters in the coastal zone of the Caribbean, CARICOMP Data Management Center, University of West Indies, Jamaica, 2001.

[30] K. A. Seedo, M. S. Abido, A. A. Salih, and A. Abahussain, "Assessing Heavy Metals Accumulation in the Leaves and Sediments of Urban Mangroves (Avicennia marina (Forsk.) Vierh.) in Bahrain," International Journal of Ecology, vol. 2017, pp. 1-8, 2017.

[31] Climate - BMD. Web. Portal., http://www.bahrainweather.gov .bh/web/guest/climate.

[32] J. B. Kauffman and D. C. Donato, "Protocols for the measurement, monitoring and reporting of structure, biomass and carbon stocks in mangrove forests," Working Paper 86, CIFOR, Bogor, Indonesia, 2012.

[33] A. W. Kuchler, D. Mueller-Dombois, and H. Ellenberg, "The Count-Plot Method and Plotless Sampling Techniques," in Aims and Methods of Vegetation Ecology, pp. 67-92, John Wiley and Sons, New York, NY, USA, 1974.

[34] L. R. Dice, "Measures of the amount of ecologic association between species," Ecology, vol. 26, pp. 297-302, 1945.

[35] E. H. Simpson, "Measurement of diversity," Nature, vol. 163, article 688, 1949.

[36] C. Raunkiaer, "The life forms of plants and statistical plant geography; being the collected papers of C. Raunkiaer," in The Geographical Journal, F. N. Egerton, Ed., vol. 84, p. 455, Oxford University Press, 1934.

[37] IUCN, Habitats Classification Scheme (Version 3.1), 2016 http://www.iucnredlist.org/technical-documents/classificationschemes/habitats-classification-scheme-ver32016.

[38] M. D. Cornes and C. D. Cornes, The wild flowering plants of Bahrain: An illustrated guide, Immel Publishing Limited, London, UK, 1989.

[39] USDA, Natural Resources Conservation Service soils: soil texture calculator, (U. S. Department of Agriculture), 2015, http://www.nrcs.usda.gov/wps/portal/nrcs/detail/soils/survey/ ?cid=nrcs142p2_054167.

[40] G. Estefan, R. Sommer, and J. Ryan, Methods of Soil, Plant, and Water Analysis: A Manual for The West Asia and North Africa Region, ICARDA, Beirut, Lebanon, 2013.

[41] JMP11, Statistical Package, SAS Corporation, Wisconsin, USA, 2014.

[42] Y. Chen and Y. Ye, "Effects of salinity and nutrient addition on mangrove excoecaria agallocha," PLoS ONE, vol. 9, no. 4, Article ID e93337, 2014.
[43] J. A. C. Pellegrini, M. L. G. Soares, F. O. Chaves et al., "A method for the classification of mangrove forests and sensitivity/vulnerability analysis," Journal of Coastal Research, vol. 56, pp. 444-447, 2009.

[44] B. F. Clough, "Growth and salt balance of the mangrove Avicennia marina in South-Eastern Australia," Australian Journal of Botany, vol. 39, pp. 283-293, 1984.

[45] E. Schulze, M. M. Caldwell, J. Canadell et al., "Downward flux of water through roots (i.e. inverse hydraulic lift) in dry Kalahari sands," Oecologia, vol. 115, no. 4, pp. 460-462, 1998.

[46] G. Naidoo, "Factors contributing to dwarfing in the mangrove Avicennia manna," Annals of Botany, vol. 97, no. 6, pp. 1095-1101, 2006.

[47] H. T. Nguyen, D. E. Stanton, N. Schmitz, G. D. Farquhar, and M. C. Ball, "Growth responses of the mangrove Avicennia marina to salinity: Development and function of shoot hydraulic systems require saline conditions," Annals of Botany, vol. 115, no. 3, pp. 397-407, 2015.

[48] P. Cardona and L. Botero, "Soil characteristics and vegetation structure in a heavily deteriorated mangrove forest in the Caribbean Coast of Colombia," Biotropica, vol. 30, no. 1, pp. 2434, 1998.

[49] K. W. Krauss and M. C. Ball, "On the halophytic nature of mangroves," Trees - Structure and Function, vol. 27, no. 1, pp. 711, 2013.

[50] N. Schmitz, E. M. R. Robert, A. Verheyden, J. G. Kairo, H. Beeckman, and N. Koedam, "A patchy growth via successive and simultaneous cambia: Key to success of the most widespread mangrove species Avicennia marina?" Annals of Botany, vol. 101, no. 1, pp. 49-58, 2008.

[51] A. S. Mandura, "A mangrove stand under sewage pollution stress: Red Sea," Mangroves and Salt Marshes, vol. 1, no. 4, pp. 255-262, 1997.

[52] F. Dahdouh-Guebas, J. G. Kairo, R. De Bondt, and N. Koedam, "Pneumatophore height and density in relation to microtopography in the grey mangroves Avicennia marina," Belgian Journal of Botany, vol. 140, no. 2, pp. 213-221, 2007, http://www.ulb.ac.be/sciences/biocomplexity/pub/DahdouhGuebasetal_2007_BelgJBot.pdf.

[53] S. M. Saifullah and E. Elahi, "Pneumatophore density and size in mangroves of Karachi," Pakistan Journal of Botany, vol. 24, no. 1, pp. 5-10, 1992, http://www.pakbs.org/pjbot/PDFs/24(1)/04.pdf.

[54] P. J. Clarke and W. G. Allaway, "The regeneration niche of the grey mangrove (Avicennia marina): effects of salinity, light and sediment factors on establishment, growth and survival in the field," Oecologia, vol. 93, no. 4, pp. 548-556, 1993.

[55] D. J. Macintosh and E. C. Ashton, A Review of Mangrove Biodiversity Conservation and Management, Centre for Tropical Ecosystem Research, University of Aarhus, Denmark, 2002.

[56] T. Noor, N. Batool, R. Mazhar, and N. Ilyas, "Effects of siltation, temperature and salinity on mangrove plants," European Academic Research, vol. 2, no. 11, pp. 14172-14179, 2015.

[57] B. M. Young and L. E. Harvey, "A spatial analysis of the relationship between mangrove (Avicennia marina var. australasica) physiognomy and sediment accretion in the Hauraki Plains, New Zealand," Estuarine, Coastal and Shelf Science, vol. 42, no. 2, pp. 231-246, 1996. 

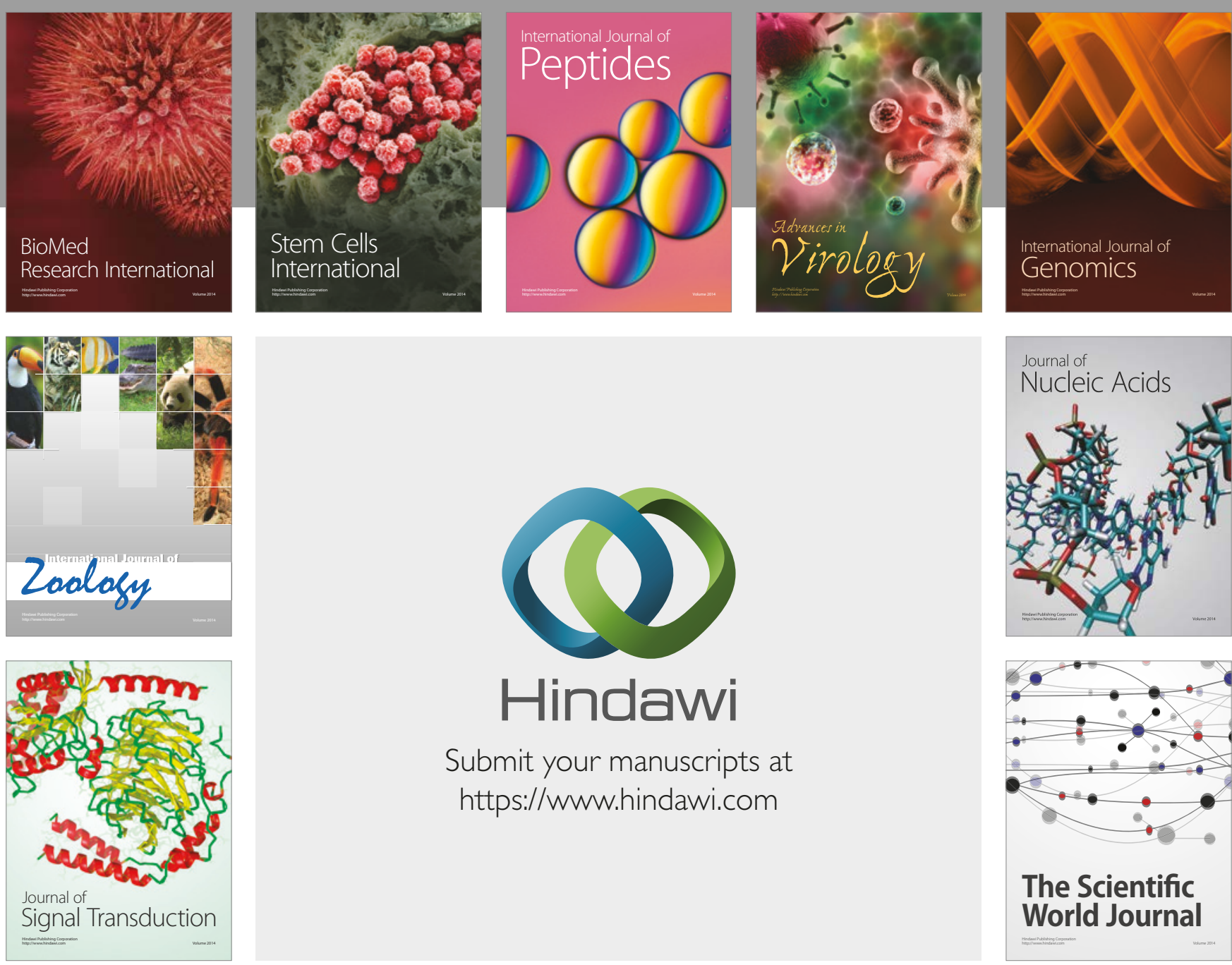

Submit your manuscripts at

https://www.hindawi.com
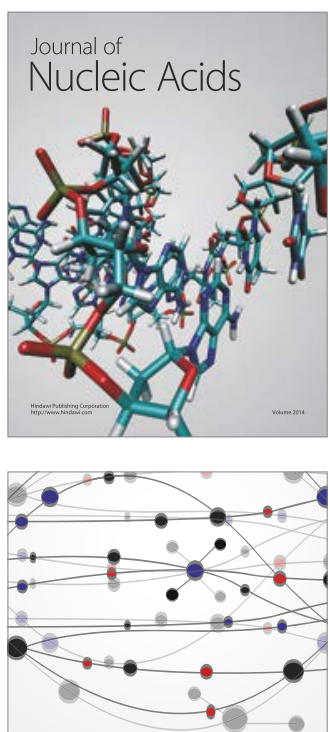

The Scientific World Journal

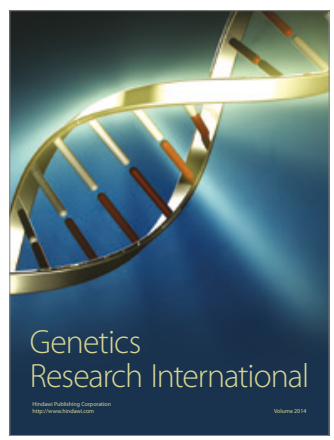

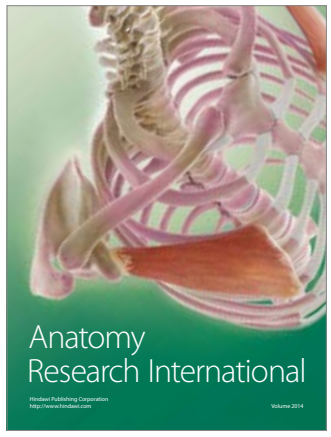

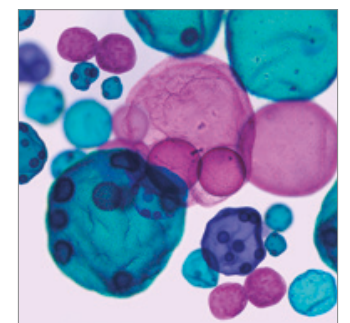

International Journal of Microbiology
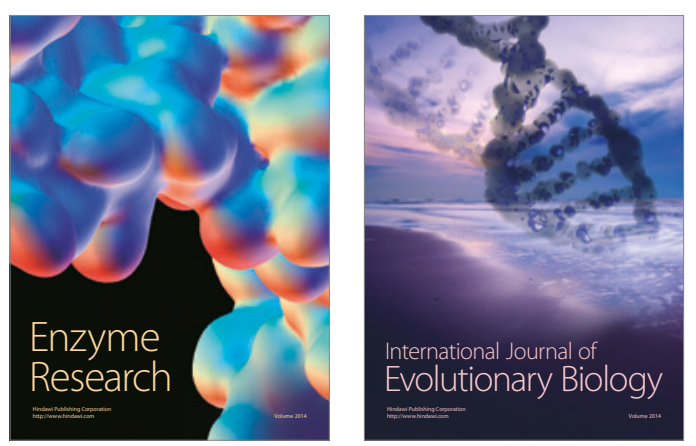
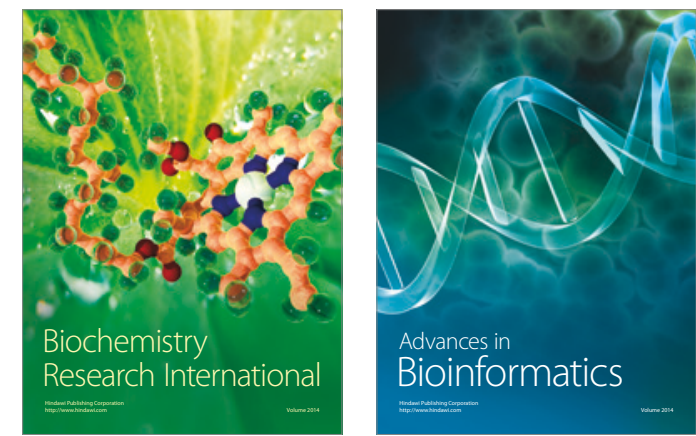

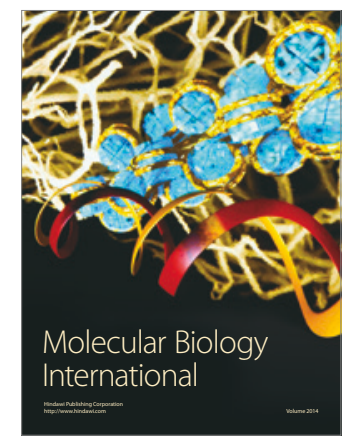

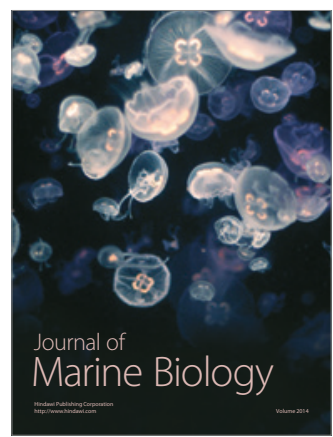

